\title{
Economic Feasibility and Technical Possibility of Net- Zero Energy Building in Tehran
}

\author{
Farhad Hekmatipour ${ }^{*}$, Milad Jalali and Ali Marofi ${ }^{2}$ \\ 'Department of Energy and Environment, Science and Research Branch, Islamic Azad University, Tehran, Iran; far- \\ had.hekmatipour@srbiau.ac.ir \\ ${ }^{2}$ Faculty of Physics, Semnan University, Iran
}

\begin{abstract}
Objectives: The economic feasibility and technical possibility of net-zero energy building in Tehran is conducted numerically in this research. Methods: The methods of numerical study and simulation were applied to calculate the economic feasibility and technical possibility of net-zero energy building in Tehran. The numerical method is conducted using C++ programming and simulation did by Hourly Analysis Program, and Poly Sun software. The results of simulation and programming are compared and presented. Findings: Simulation shows that the majority of energy which is needed for cooling and heating could be declined using insulation and better material for making building. It is observed that gas and electricity consumption stood at $50970 \mathrm{~kW}$ and $14772 \mathrm{~kW}$, respectively. After insulation, Gas demand and electricity consumption declined dramatically to reach $23270 \mathrm{~kW}$ and $10574.6 \mathrm{~kW}$, respectively. The calculation of Trombe wall, ground Heat Pump, Photovoltaic is conducted using simulation and $\mathrm{C}++$ programming. The results of programming and simulation show that Solar collector can produce $10209.8 \mathrm{kWh} /$ year, and ground source Heat pump produces 7009.5 $\mathrm{kWh} /$ year, Photovoltaic panels produce $58.06 \%$ of the total electricity demand. This system can provide $74 \%$ of heating and cooling load and $68.3 \%$ of total energy which is consumed in the building. Application and Improvement: The reduction of energy consumption in building is very important these days and it is possible by insulation and Trombe wall. The majority of energy consumption can be provided using renewable resources in the building.
\end{abstract}

Keywords: Ground Source Heat Pump, Net-Zero Energy Building, Photovoltaic Panel

\section{Introduction}

Through these studies, scientists observed that the majority of final energy has been consumed by the building sector in the world. This means that Domestic, commercial and official sectors used one out of three or one quarter of energy, which is produced in the world. Some researchers are presented as is the following:

Nowadays, energy modelling has done with the using optimum HVAC energy system and building energy management. For example, in studies carried out ${ }^{1-3}$. Hourly building energy simulation program was applied to be evaluated heating and cooling load in the building and this study reduced the amount of energy demand in the buildings ${ }^{4}$. An optimization model was developed with the using the hourly building energy simulation program to simulate the optimum thermal design of the building envelope $\mathrm{e}^{5}$.

\section{List of symbols}

\begin{tabular}{|l|l|}
\hline $\begin{array}{l}\mathrm{A}_{\mathrm{i}} \text { internal contact area } \\
(\mathrm{m})\end{array}$ & $\begin{array}{l}\mathrm{R}_{\mathrm{s}} \text { soil thermal resistance } \\
\left(\mathrm{m}^{2} \cdot \mathrm{K} / \mathrm{w}\right)\end{array}$ \\
\hline $\begin{array}{l}\mathrm{A}_{\mathrm{o}} \text { external contact area } \\
(\mathrm{m})\end{array}$ & $\mathrm{T}$ temperature $(\mathrm{K})$ \\
\hline $\begin{array}{l}\text { COP } \\
\text { performance }\end{array}$ & $\mathrm{T}_{\mathrm{c}}$ ambient temperature $(\mathrm{K})$ \\
\hline $\begin{array}{l}\mathrm{COP}_{\mathrm{h}} \text { heating coefficient } \\
\text { of performance }\end{array}$ & $\mathrm{T}_{\mathrm{d}}$ collector temperature $(\mathrm{K})$ \\
\hline $\mathrm{F}_{\mathrm{h}}$ part load factor & $\begin{array}{l}\mathrm{T}_{\mathrm{e}} \text { external temperature } \\
\text { constructed the Trombe wall } \\
(\mathrm{k})\end{array}$ \\
\hline
\end{tabular}




\begin{tabular}{|c|c|}
\hline $\begin{array}{l}h_{i} \text { internal convection } \\
\text { heat transfer }\left(w / \mathrm{m}^{2} \cdot \mathrm{K}\right)\end{array}$ & $\begin{array}{l}\mathrm{T}_{\text {ewt,min }} \text { minimum design } \\
\text { entering temperature }(\mathrm{K})\end{array}$ \\
\hline $\begin{array}{l}h_{o} \text { external convection } \\
\text { heat transfer }\left(\mathrm{w} / \mathrm{m}^{2} \cdot \mathrm{K}\right)\end{array}$ & $\begin{array}{l}\mathrm{T}_{\mathrm{g} \text { 'min }} \text { minimum undisturbed } \\
\text { ground temperature }(\mathrm{K})\end{array}$ \\
\hline $\begin{array}{l}\mathrm{Hz} \text { heat transfer } \\
\text { coefficient of collector }\end{array}$ & $\mathrm{T}_{\mathrm{i}}$ indoor temperature $(\mathrm{k})$ \\
\hline I radiation intensity & $\begin{array}{l}\mathrm{T}_{\mathrm{sa}} \text { radiation temperature of } \\
\text { Trombe wall }(\mathrm{K})\end{array}$ \\
\hline $\mathrm{I}_{\mathrm{g}}$ global solar irradiation & $\begin{array}{l}\mathrm{U} \text { overall heat transfer } \\
\text { coefficient }\left(\mathrm{w} / \mathrm{m}^{2} . \mathrm{K}\right)\end{array}$ \\
\hline $\begin{array}{l}\mathrm{L}_{c} \text { length of cooling pipe } \\
(\mathrm{m})\end{array}$ & $\begin{array}{l}\mathrm{U}_{1} \text { heat loss coefficient }(\mathrm{w} / \\
\left.\mathrm{m}^{2} . \mathrm{K}\right)\end{array}$ \\
\hline $\mathrm{L}_{\mathrm{h}}$ length of hot pipe $(\mathrm{m})$ & $\mathrm{V}$ volumetric flow rate $\left(\mathrm{m}^{3} / \mathrm{s}\right)$ \\
\hline $\mathrm{Q}$ thermal loads (kW) & a radiation coefficient \\
\hline $\begin{array}{l}\mathrm{q}_{\mathrm{Hw}} \text { heat transfer }(\mathrm{kWh} / \\
\left.\mathrm{m}^{2} . \mathrm{yr}\right)\end{array}$ & $\beta$ absorbing coefficient \\
\hline $\mathrm{q}_{\mathrm{w}}$ heat flux $(\mathrm{kW})$ & $\begin{array}{l}\tau \text { light transmittance } \\
\text { coefficient }\end{array}$ \\
\hline $\begin{array}{l}\mathrm{R}_{\mathrm{p}} \text { pope thermal } \\
\text { resistance }\left(\mathrm{m}^{2} \cdot \mathrm{K} / \mathrm{w}\right)\end{array}$ & \\
\hline
\end{tabular}

A numerical investigation of the optimum thermal design of building in Riyadh and Jeddah was conducted ${ }^{6}$.

A new simulation model was presented to investigate energy consumption in the building ${ }^{\underline{p}}$. Metaheuristic simulation-EP (evolutionary programming) and non-linear programming was used to develop the evolutionary model ${ }^{\mathrm{T}}$.

Two simulation software (TAS and TRNSYS) were applied to study solar system parameter ${ }^{8}$. The cost of the passive strategies with the using building material, window size and shading devices was assessed. TRNSYS software was used to perform a numerical investigation to optimize energy consumption in the building 9 . Through this investigation, GA and LCI models are employed to introduce the new simulation model in the building?

People the indoor environment by opening windows; the cooling potential of opening windows; and the use of an adaptive algorithm for predicting window-opening behaviour for thermal simulation in ESP-r model was simulated ${ }^{10}$.

Co-simulation was suggested by the optimizing integrated HVAC system in the building. Based on this method, Building Performance Simulation (BPS) tool was designed this model employed $\frac{12}{}$.

Potential of energy saving in hypermarket HVAC system is calculated by Urbikain M.K, whereas Energy Savings Estimation Model (ESEM) is employed ${ }^{12-14}$.
An integrated methodology is used to evaluate the energy performance of the building enclosures. This model is applied ${ }^{15-18}$.

The thermal performance is investigated by mass method in different kind of research. This method is gained ${ }^{19-21}$.

Building Performance Optimization (PBO) is used ${ }^{22}$. Building performance was simulated with Energy plus $s^{2 \underline{3}}$.

New method introduced for energy modelling in the building is analysed ${ }^{24}$. Load and HVAC models were simulated by software $\underline{25}$.

Now days, Load Match (LM) and Grid Interaction (GI) is applied to predict the performance of Net ZEB $26-28$.

Nowadays, TRAN Build models are used to simulate the Combined Heat and Power (CHP) and Domestic Hot Water (DHW). This model is used in different researches ${ }^{29-31}$.

Multiple-Linear Perceptron (MLP) was used to design a new model for chiller, pump, and fan and reheat device ${ }^{32}$. Energy consumption was optimized in the building ${ }^{32}$. New model with controllable and uncontrollable input and variable output was presented to predict the energy consumption ${ }^{32}$. Computational intelligence algorithms were developed to design a new model and the minimization of energy, consumed by the HVAC ${ }^{33}$. In fact, cooling and heating load is applied to compute the energy consumption in the building ${ }^{33}$. This investigation is sought to provide thermal comfort $\frac{34}{}$.

Various methods, which gained to introduce a new model for calculating the Heating, Ventilation, and Air Conditioning (HVAC) energy system was analysed. TRCA Archetype Sustainable House (TRCA-ACH) was applied to conduct simulation on the HVAC system with the using a Ground Source Heat Pump (GSHP) in buildings in Ontario, Canada ${ }^{35}$.

Non- dominated Genetic Algorithm (NSGA-II) and multi objective optimization is applied to investigate interaction between the demand for energy in buildings and renewable energy ${ }^{36}$.

In this research it will be assumed that the total energy consumption in luxury family housing in Iran can be provided by using two renewable sources such as solar andgeothermal energy. In this work we will also employ Tromble wall to reduce the demand for energy in this building? At first, energy demand for HVAC system and non- HVAC systems in standard condition will be simulated by HAP 4.5vs (Carrier Corporation, 2012). Through this simulation, Polysun 6.2.918113 (Vela Solaris, 2013) 
is applied to simulate combined heat and power with the using ground source heat pump and solar energy.The solar collector, photovoltaic cells and Ground heat pump are used to be provided the energy which is needed for heating and cooling of building. The Photovoltaic system is designed to be traded electricity to national network and provide the energy for electrical gadgets and lighting for this building. The results might be used to improve efficiency of buildings and in decreasing air pollution from household, commercial, and public buildings.

\section{Theory}

The overall heat transfer coefficient was calculated by using heat loss and heating and cooling load ${ }^{37}$. As follows:

$$
U=\frac{1}{\left(\frac{1}{h_{i} \cdot A_{i}}+R_{1}+\ldots+R_{n}+\frac{1}{h_{o} \cdot A_{o}}\right)}
$$

The storage of heating water consumption is calculated, as follows:

$$
Q=V \times 9.79 \times\left(\mathrm{T}_{2}-T_{1}\right) \quad(\mathrm{kW})
$$

It should be mentioned that the amount of light and water consumption are calculated based on the standard of Ashrae ${ }^{38}$ and the standard of ASPE ${ }^{39}$.

\section{Case Study Description}

The characteristic of the building, including area, area of windows, electricity consumption and heating and cooling load is presented in Table 1.

Table 1. The characteristic of house

\begin{tabular}{|l|l|}
\hline Items & Value \\
\hline Building area $\left(\mathrm{m}^{2}\right)$ & 164.5 \\
\hline Area of windows $\left(\mathrm{m}^{2}\right)$ & 19.8 \\
\hline Electricity consumption $(\mathrm{kWh})$ & 14772 \\
\hline Heat and cooling loads $(\mathrm{kWh})$ & 65742 \\
\hline Hot water storage (liter) & 3 \\
\hline
\end{tabular}

Figure 1 shows that the building area and area of the windows are $164 \mathrm{~m}^{2}$, and $19.8 \mathrm{~m}^{2}$, respectively. The amount of lighting is 1.5 to $2 \mathrm{w} / \mathrm{m}^{2}$. The energy class is A. The average duration of lighting of lighting is considered
$5 \mathrm{hr} /$ day. As a result, the total electricity which is needed to be used for lighting is $4740 \mathrm{kWh} / \mathrm{yr}$. The calculation shows that the electrical equipment needs $2409 \mathrm{kWh} /$ $\mathrm{yr}$ and the average duration of using electrical gadgets is considered for $4 \mathrm{hr} /$ day. The ground heat pump does not need to consume lots of electricity because it is water to water heat pump and it uses gravity and natural circulation. The model of the ground heat pump is BW113.2 made by SATAG Thermotechnik AG. It can produce 11.7 $\mathrm{kW}$. In addition, electrical equipment and lighting system use $7149 \mathrm{kWh} / \mathrm{yr}$. Based on the result, heating and cooling equipment used $65742 \mathrm{kWh} / \mathrm{yr}$. In this project uses the ground heat pump, which does need to consume less electrical energy. In fact, it is a heat exchanger which used electricity for pumping only. Another point that should be mentioned is that heating and cooling loads and electrical consumption are computed by hourly analysis program 4.5 views, and the calculation is based on using thermal conductivity coefficient of building material, which is illustrated in Table 2. Moreover, indoor temperatures in winter and summer are assumed $21.2^{\circ} \mathrm{C}$ and $23^{\circ} \mathrm{C}$, respectively.

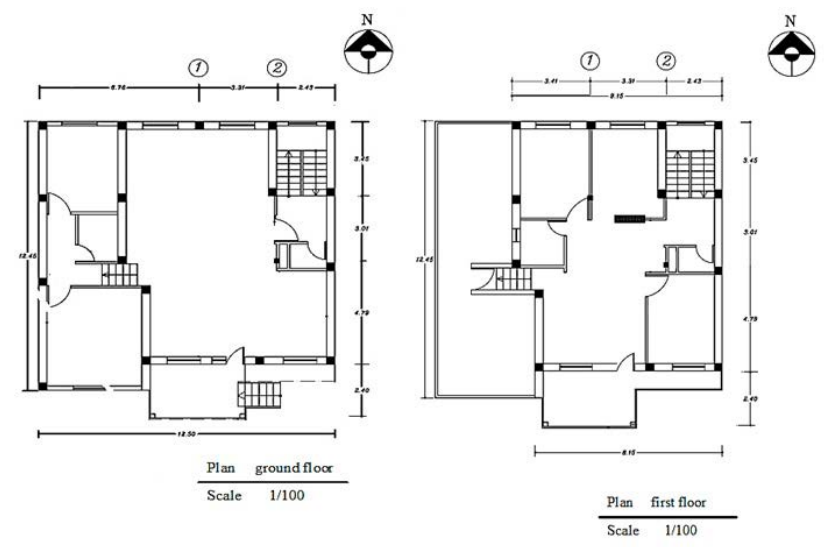

Figure 1. The plan of building.

Besides, hot water consumption and hot water storage are calculated ${ }^{39}$. The water consumption, storage is 300 liter.

\section{Method of Designing Net-Zero Energy Building}

\subsection{Passive Method}

Comparison of the electricity and gas consumption before and after simulation is presented in Figure 2. It is 
Table 2. The characteristic of building material

\begin{tabular}{|c|c|c|c|c|}
\hline & Building material & $\begin{array}{l}\text { Thickness } \\
(\mathrm{mm})\end{array}$ & $\begin{array}{l}\text { Heat transfer } \\
\text { coefficient }\left(\mathrm{W} / \mathrm{m}^{2} . \mathrm{K}\right)\end{array}$ & $\begin{array}{l}\text { Heat resistance } \\
\left(\mathrm{m}^{2} / \mathrm{w} . \mathrm{k}\right)\end{array}$ \\
\hline \multirow{4}{*}{\begin{tabular}{l} 
पे \\
0 \\
\hdashline
\end{tabular}} & Plasterboard & 25 & 0.5 & 0.05 \\
\hline & Polystyrene & 40 & 0.058 & 0.689 \\
\hline & Roof brick & 105 & - & 0.13 \\
\hline & Roof insulation & 10 & 0.7 & 0.054 \\
\hline \multirow[b]{4}{*}{ 言 } & Plasterboard & 25 & 0.5 & 0.05 \\
\hline & Polystyrene & 40 & 0.058 & 0.689 \\
\hline & Common Brick & 105 & - & 0.09 \\
\hline & Concrete & 20 & 1.75 & 0.011 \\
\hline
\end{tabular}

observed that gas and electricity consumption stood at $50970 \mathrm{~kW}$ and $14772 \mathrm{~kW}$, respectively.

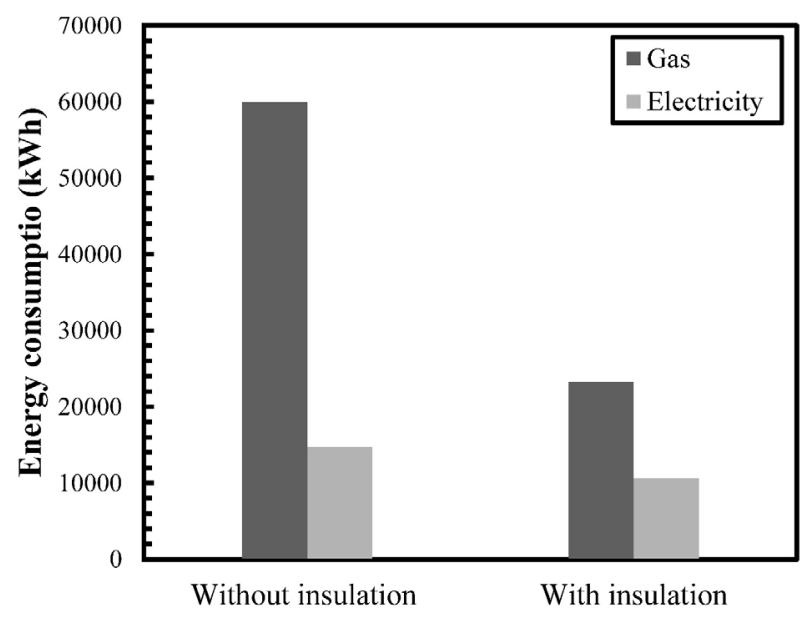

Figure 2. Comparison of the electricity and gas consumption before and after simulation.

After insulation, Gas demand and electricity consumption declined dramatically to reach $23270 \mathrm{~kW}$ and $10574.6 \mathrm{~kW}$, respectively.

\subsubsection{Trombe Wall}

The Trombe wall is constructed from heat absorbing material with thickness of $20 \mathrm{~cm}$ to $40 \mathrm{~cm}$, and the surfaces of material, which has absorbed radiation heat, is dark color ${ }^{40}$. Furthermore, one or double glazing put in front of an exterior Trombe wall and distance between wall and glazing are $15 \mathrm{~mm}$ to $20 \mathrm{~mm}$. The cell temperature is calculated with using the ambient temperature and radiation heat transfer, absorbing in the Trombe wall. That is evaluated by eq. (3):

$$
T_{s a}=T_{e}+\frac{\alpha I_{g}}{h_{c}}\left({ }^{\circ} \mathrm{C}\right)
$$

Heat flux transferred inside of the room is obtained from the Eq. (3):

$$
q_{w}=U\left(T_{i}-T_{s a}\right)\left(\mathrm{w} / \mathrm{m}^{2}\right)
$$

\subsubsection{Most of Lighting Bulb and Electric Device}

The number of lighting bulbs are considered based on $1.5\left(\mathrm{w} / \mathrm{ft}^{2}\right)$ to $2\left(\mathrm{w} / \mathrm{ft}^{2}\right)$ and the rate of electricity consumptions are calculated in different part of building such as primary room, hall, dining room, ground floor, second floor room, and kitchen, (During lighting, device electricity and during of light, date by using electrical equipment is 4 or 5 in this building.

\subsection{Renewable Resources}

The energy demand of building can be supplied with the using active solar method and renewable resource such as solar, geothermal. In this article, solar active method and ground source heat pump are appliedto providing the energy demand. In addition, radiator with various temperature ranges between $60^{\circ} \mathrm{C}$ to $125^{\circ}$ can be used in the ground source heat pump. Furthermore, cooling is feasible to be supplied by using reverse cycle of heating process. The efficiency of ground source heat pump is almost $70 \%$. In addition, the Length of pipe achieves by Eq. (5) and (6) ${ }^{41}$ : 


$$
\begin{aligned}
& L_{h}=q_{d, \text { heat }}\left[\frac{\frac{\left(\operatorname{Cop}_{h}-1\right)}{\operatorname{Cop}_{h}}\left(R_{p}+R_{s} F_{h}\right)}{T_{g, \min }-T_{\text {ewt }, \text { in }}}\right] \\
& L_{c}=q_{d, \text { cool }}\left[\frac{\frac{\left(\operatorname{Cop}_{c}-1\right)}{\operatorname{Cop}_{c}}\left(R_{p}+R_{s} F_{c}\right)}{T_{e w t, \text { max }}-T_{g, \max }}\right]
\end{aligned}
$$

This point should be mentioned that ground source heat pump is computed with $\mathrm{C}++$ code. Furthermore, the length of the tube is considered $140 \mathrm{~m}$, and it is placed vertically.

\subsubsection{Solar Collector and Photovoltaic}

The number of solar collectors is calculated by using the amounts of hot water consumption, and it is also shown in Table 3. Moreover, it is calculated by using the characteristic of solar collector glass and Hottle-Whillier

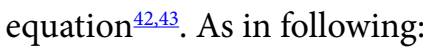

$$
q_{H W}=\tau \beta I-U_{L}\left(T_{d}-T_{c}\right)\left(\mathrm{kWh} / \mathrm{m}^{2} \cdot \mathrm{yr}\right)
$$

Table 3. The characteristic of building material

\begin{tabular}{|l|l|}
\hline Item & W \\
\hline 400 & 1 \\
\hline 1000 & 2 \\
\hline 600 & 3 \\
\hline 400 & 4 \\
\hline
\end{tabular}

\section{Result and Discussion}

The solar collector manufacture is Shandong Linuo New Material Co., Ltd and the model of collector is LN-RGWF-1.6/16-47-1500-A. The characteristics of the solar collector are presented in Table 4. It is observed that the absorption coefficient and the light transmittance coefficient were $93 \%$, and $91.6 \%$, respectively. Once the temperature of the collectors is $50^{\circ} \mathrm{C}$, and the area of solar collector placed is $31.5 \mathrm{~m}^{2}$.Overall heat loss coefficient of single-glazed collector is $1.98 \mathrm{w} / \mathrm{m} . \mathrm{k}$ in winter. Then, overall heat loss coefficient of solar collector is calculated as $1.51 \mathrm{kWh} / \mathrm{m}^{2}$.

\section{The features of solar collector}

\begin{tabular}{|l|l|l|l|}
\hline Property & Float & Sheet lime & White \\
\hline $\begin{array}{l}\text { Iron-oxide content, percent } \\
(\%)\end{array}$ & 0.12 & 0.12 & 0.01 \\
\hline Reflective index & 1.52 & 1.52 & 1.5 \\
\hline $\begin{array}{l}\text { Light transmittance }(\tau), \\
\text { percent }(\%)\end{array}$ & 84 & 84 & 91.6 \\
\hline Reflective loss, percent $(\%)$ & $8.2-8$ & $8.2-8$ & 8 \\
\hline $\begin{array}{l}\text { Absorption loss, percent } \\
(\%)\end{array}$ & $8.0-13$ & $8.0-13$ & under \\
\hline
\end{tabular}

The weather data is shown in Table 4 . Then, the weather data and the characteristic of collectors are used to calculate the amount of radiation energy, which is absorbed by solar collectors on January $21^{\text {st }}$, the solar energy, which is absorbed on January 21st. Based on the results, the maximum of the solar energy is absorbed in 1 P.M.

The amount of solar energy, which is absorbed by solar collector in the year, is shown in Figure 3. By using 8 collectors, it is possible to absorb the wide range of solar radiation from $1.4\left(\mathrm{kWh} / \mathrm{m}^{2}\right.$. Day) to $5.7\left(\mathrm{kWh} / \mathrm{m}^{2}\right.$.Day). According to the hours of operation and the area of the collector which is $31.5 \mathrm{~m}^{2}$, the sum of energy, which is absorbed by solar collector, is about $10298 \mathrm{kWh} / \mathrm{yr}$. As a result, the part of the heating and cooling loads are supplied because the energy, consumed in different part of the building, including heating water consumption, heating and cooling system, and hot water is about 23270.2 $\mathrm{kWh} / \mathrm{yr}$. Furthermore, this system can provide $51.3 \%$ of total thermal loads. This system can also provide $76.5 \%$

Table 4. The weather data on January 21 st

\begin{tabular}{|l|l|l|l|l|l|l|l|l|l|l|l|l|}
\hline Hour & 1 & 2 & 3 & 4 & 5 & 6 & 7 & 8 & 9 & 10 & 11 & 12 \\
\hline $\mathrm{T}\left({ }^{\circ} \mathrm{C}\right)$ & -0.93 & -1.01 & -1.11 & -1.20 & 0.22 & 1.18 & 2.12 & 3.83 & 4.30 & 5.00 & 5.30 & 4.75 \\
\hline Hour & 13 & 14 & 15 & 16 & 17 & 18 & 19 & 20 & 21 & 22 & 23 & 24 \\
\hline $\mathrm{T}\left({ }^{\circ} \mathrm{C}\right)$ & 4.40 & 3.13 & 2.65 & 2.24 & 1.89 & 1.6 & 1.35 & 1.22 & 1.10 & 0.99 & -0.88 & -0.86 \\
\hline
\end{tabular}


Table 5. The amount of energy is supplied by geothermal heat pump

\begin{tabular}{|c|c|c|c|c|c|c|c|c|c|c|c|c|c|}
\hline 苋 & $\begin{array}{l}\text { ¿े } \\
\text { }\end{array}$ & 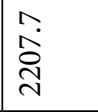 & - & $\stackrel{0}{-1}$ & $\begin{array}{l}\text { Ha } \\
\text { in }\end{array}$ & $\stackrel{\infty}{i}$ & $\stackrel{\text { ô. }}{0}$ & $\begin{array}{l}m \\
\infty\end{array}$ & $\stackrel{\infty}{\rightarrow}$ & $\begin{array}{l}0 \\
\dot{1} \\
\dot{1}\end{array}$ & $\stackrel{\widehat{I}}{\mathrm{I}}$ & $\begin{array}{l}9 \\
10 \\
10 \\
\end{array}$ & 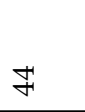 \\
\hline$\vec{z}$ & $\begin{array}{l}\stackrel{\text { }}{ } \\
\text { m. }\end{array}$ & $\frac{\partial}{\vec{m}}$ & $\stackrel{9}{-}$ & $\overrightarrow{0}$ & $\stackrel{\infty}{\stackrel{\infty}{\triangle}}$ & $\hat{m}$ & نْ- & $\stackrel{\circ}{\circ}$ & $\frac{9}{i}$ & भे & $\stackrel{\rightleftarrows}{\rightleftarrows}$ & \begin{tabular}{l}
$n$ \\
\multirow{i}{*}{} \\
$\alpha$
\end{tabular} & $\begin{array}{l}\text { ம் } \\
\dot{q}\end{array}$ \\
\hline$\ddot{\tilde{U}}$ & 0 & 0 & 0 & 0 & 0 & 0 & 0 & 0 & 0 & 0 & 0 & 0 & 0 \\
\hline ळें & 0 & 0 & 0 & 0 & 0 & 0 & 0 & 0 & 0 & 0 & 0 & 0 & 0 \\
\hline$\frac{00}{2}$ & 0 & 0 & 0 & 0 & 0 & 0 & 0 & 0 & 0 & 0 & 0 & 0 & 0 \\
\hline$\Xi$ & 0 & 0 & 0 & 0 & 0 & 0 & 0 & 0 & 0 & 0 & 0 & 0 & 0 \\
\hline$\Xi$ & 0 & 0 & 0 & 0 & 0 & 0 & 0 & 0 & 0 & 0 & 0 & 0 & 0 \\
\hline 至 & 0 & 0 & 0 & 0 & 0 & 0 & 0 & 0 & 0 & 0 & 0 & 0 & 0 \\
\hline $\overrightarrow{\mathrm{a}}$ & 0 & 0 & 0 & 0 & 0 & 0 & 0 & 0 & 0 & 0 & 0 & 0 & 0 \\
\hline 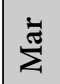 & 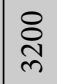 & $\begin{array}{l}\infty \\
\tilde{n} \\
i n\end{array}$ & 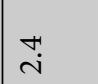 & 1n? & $\underset{J}{\stackrel{H}{J}}$ & $\stackrel{m}{+}$ & $\overrightarrow{\mathrm{i}}$ & $\stackrel{\infty}{a}$ & $\stackrel{9}{\rightarrow}$ & ঙ্ & $\hat{\sigma}$ & 望 & 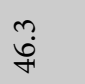 \\
\hline बे & $\begin{array}{l}\text { ¿ి } \\
\text { nె }\end{array}$ & $\begin{array}{l}0 \\
0 \\
0 \\
0\end{array}$ & $\sim$ & $\overrightarrow{0}$ & $\vec{n}$ & ले & 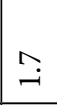 & $a$ & $\stackrel{9}{-}$ & 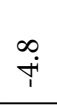 & $\stackrel{\rightleftarrows}{=}$ & 离 & $\begin{array}{l}\hat{q} \\
\dot{q}\end{array}$ \\
\hline 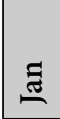 & $\begin{array}{l}8 \\
\text { तె } \\
\text { m. }\end{array}$ & 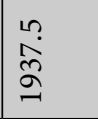 & $\stackrel{n}{-}$ & $\stackrel{10}{7}$ & $\stackrel{b}{\stackrel{0}{\triangle}}$ & $\stackrel{m}{m}$ & $\begin{array}{l}\tilde{O} \\
0\end{array}$ & $\ddot{a}$ & $\stackrel{9}{\rightarrow}$ & $\begin{array}{l}\infty \\
\dot{p} \\
\dot{1}\end{array}$ & $\begin{array}{l}\text { in } \\
\text { in }\end{array}$ & 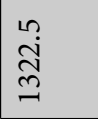 & 而 \\
\hline હ્ّ & $\begin{array}{l}8 \\
\text { लె } \\
\end{array}$ & 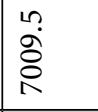 & $\stackrel{n}{\longrightarrow}$ & & $\stackrel{\infty}{\stackrel{\infty}{\triangle}}$ & $\stackrel{\ddot{m}}{\ddot{m}}$ & 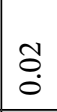 & $\stackrel{\infty}{\sigma}$ & $\frac{9}{7}$ & $\begin{array}{l}0 \\
\dot{1} \\
1\end{array}$ & $\begin{array}{l}10 \\
\text { in }\end{array}$ & 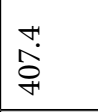 & $\stackrel{2}{f}$ \\
\hline$\stackrel{\bar{\Xi}}{\mathbf{s}}$ & 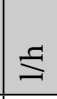 & $\sum_{1}^{5}$ & 0 & 0 & 0 & 0 & U & U & 0 & 0 & 0 & 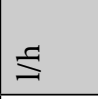 & $\frac{\xi}{3}$ \\
\hline $\begin{array}{l}\text { ב̆ } \\
\text { Zू̃ }\end{array}$ & 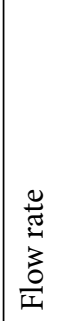 & 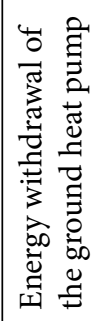 & 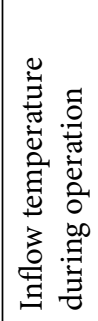 & 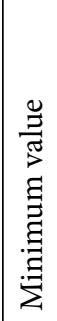 & 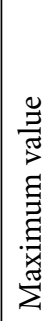 & 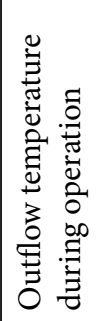 & 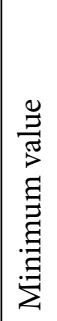 & 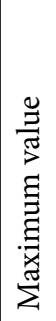 & 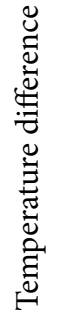 & 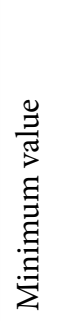 & 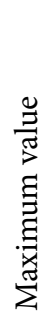 & 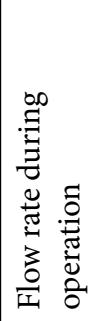 & 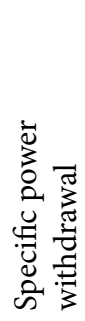 \\
\hline
\end{tabular}


of hot water system. According to the Figure 3, 10764.4 $\mathrm{kWh} / \mathrm{yr}$ of solar thermal energy is absorbed by using combined heat and power with ground heat pump and solar collectors. Furthermore, it can be observed that the amount of fuel or electricity consumption is supplied by this system, and it is about $3613.4 \mathrm{kWh}$.

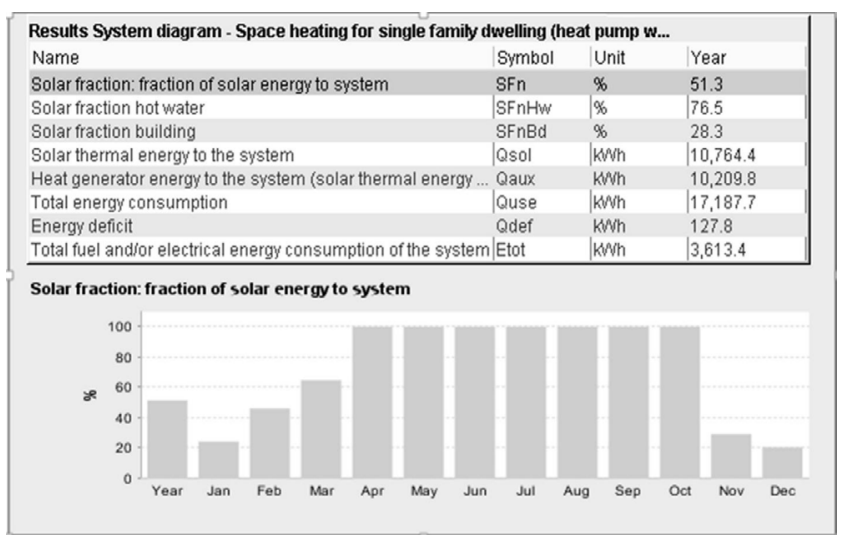

Figure 3. The amount of absorbed solar energy by collectors.

According the Table 5, ground source heat pump produces $7009.5 \mathrm{kWh} / \mathrm{yr}$. In addition, this system just used for heating in winter as a result, solar energy and geothermal energy together generate $17764.4 \mathrm{kWh} / \mathrm{yr}$. of the demand for energy in the building since energy demand is about $23270.2 \mathrm{~kW}$. In addition, it can provide the most proportion of the thermal load, which is $76.34 \%$ of heating and hot water consumption.

The Photovoltaic Cells are built by Changzhou Nesl Solartech Co., Ltd. The name of photovoltaic cell is DJ-280P and the efficiency of cell is 0.14452 . The area of Photovoltaic cells is $98.9 \mathrm{~m}^{2}$. According to Figure 4, Photovoltaic panel can produce $6140 \mathrm{kWh} / \mathrm{yr}$. As a result, the portion of power consumption is provided by Photovoltaic panel. In addition, the amount of electricity demands for non - HVAC facilities and HVAC facility are $10574.6 \mathrm{kWh}$. This system can also provide $58.06 \%$ of total device electricity per year. This project is designed to be traded by the national network, so the electricity which is produced in summer is sold to the national network. The economic efficiency is calculated to improve the economic efficiency in this building.

Facility and HVAC facility are $10574.6 \mathrm{kWh}$. Furthermore, this system can provide $58.06 \%$ of total device electricity year. To sum up, this system can provide $78 \%$ of heating and cooling energy and it can supply $69.83 \%$ of the total energy demand.

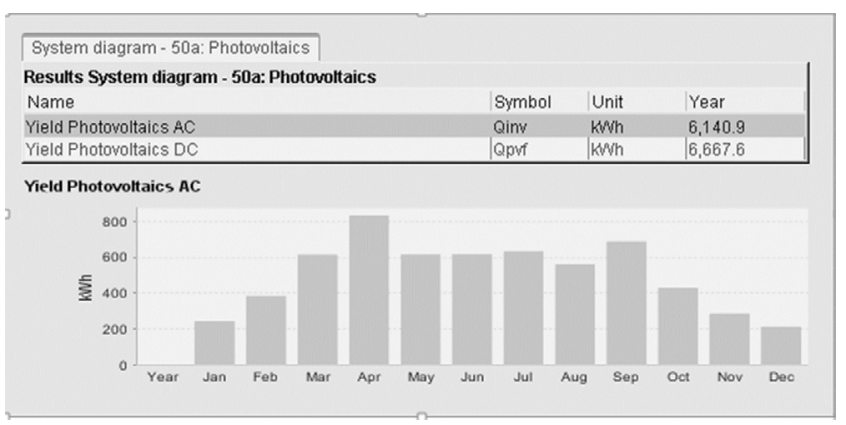

Figure 4. Electricity is produced by photovoltaic.

\subsection{Economic Assessment}

The investment and operating cost are presented in Table 6. Investing cost and operating cost are about $26146 \$$ and 818.33 \$, respectively. However, these systems are led to reduce the energy cost in the year and the amount of saving money is about $4991.81 \$$ per year. According to Table 7, IRR is evaluated based on various inflation rates, including $3 \%, 10 \%$, and $20 \%$, and interest rate $17 \%$. IRR obtains 0.03 and therefore payback time is 20.8 years.

Table 6. investment and operating cost

\begin{tabular}{|c|c|c|}
\hline & Equipment & Price $(\$)$ \\
\hline \multirow{6}{*}{ 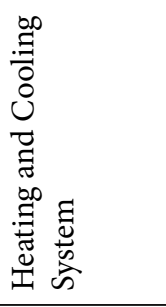 } & Collector & 1930 \\
\hline & Cost of installation & 200 \\
\hline & Storage & 2770 \\
\hline & Pluming & 6680 \\
\hline & Pump & 340 \\
\hline & Heat Exchanger & 145 \\
\hline \multirow{4}{*}{ 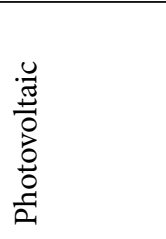 } & Installation & 165 \\
\hline & Inventor & 4620 \\
\hline & Batteries & 280 \\
\hline & Cells & 8580 \\
\hline \multirow{2}{*}{ 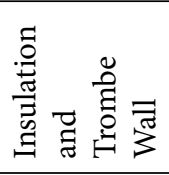 } & $\begin{array}{l}\text { Insulation and } \\
\text { Trombe wall }\end{array}$ & 290 \\
\hline & Glazing & 146 \\
\hline \multicolumn{2}{|l|}{ Sum } & 26146 \\
\hline
\end{tabular}

Table 7. Economic assessment

\begin{tabular}{|l|l|l|l|}
\hline \multicolumn{4}{|l|}{ Economic assessment } \\
\hline $\begin{array}{l}\text { Inflation } \\
\text { rate }\end{array}$ & NPV (\$) & IRR & $\begin{array}{l}\text { Investment } \\
\text { return }\end{array}$ \\
\hline $3 \%$ & -375000 & --- & --- \\
\hline $10 \%$ & -175000 & --- & --- \\
\hline
\end{tabular}




\begin{tabular}{|l|l|l|l|}
\hline $20 \%$ & 108000 & 0.03 & 20.8 \\
\hline
\end{tabular}

\section{Conclusion}

In this research, the effect of using solar collector, photovoltaic panel, ground heat pump, and the Trombe wall was investigated theoretically in the house. The results may be summarized as follows:

1. Solar collector can produce $10209.8 \mathrm{kWh} /$ year, and $53.1 \%$ of total thermal load is provided by the solar collectors.

2. The ground source Heat pump produces $7009.5 \mathrm{kWh} /$ year, and it supplies $29.5 \%$ of total thermal load.

3. Photovoltaic panels produce $58.06 \%$ of the total electricity demand.

4. by using the Trombe wall and wall and roof insulation are decreased two out of three of heating and cooling loads.

5. This system can provide $74 \%$ of heating and cooling load and $68.3 \%$ of total energy which is consumed in the building.

6. IRR and payback time are 0.03 and 20.8 years, respectively.

According to the results, using the wall and roof insulation and renewable energy equipmenthas been provided the most proportion of the energy demand in the building. In fact, these provide $68.3 \%$ of total energy.

\section{Reference}

1. Meckler M. The computer approach to comprehensive building envelope optimization studied, Journal of Thermal Insulation. 1982; 5:161-72. https://doi. org/10.1177/109719638200500304.

2. Nassif N, Moujaes S, Zaheeruddin M. Self-tuning dynamic models of HVAC system components, Energy and Buildings. 2008; 40(9):1709-20. https://doi.org/10.1016/j. enbuild.2008.02.026.

3. Raftery P, Keane M and Costa A. Calibrating whole building energy models; detailed case study using hourly measured data, Energy and Buildings. 2011; 43(12):3666-79. https:// doi.org/10.1016/j.enbuild.2011.09.039.

4. Al-Homoud MS. The effectiveness of Thermal insulation in different types of building in hotclimate, Journal of Thermal Envelope and Building Science. 2004; 27(3):235-47. https:// doi.org/10.1177/1097196304038368.
5. Al-Homoud MS. A systematic approach for the thermal design optimization of building envelopes, Journal of Building Physics. 2005; 29(2):95-119. https://doi. org/10.1177/1744259105056267.

6. Al-homoud MS. Envelop Thermal design optimization of building of buildings with Intermittent Occupancy, Journal of Building Physics. 2009; 33(1):65-82. https://doi. org/10.1177/1744259109102799.

7. Fong KF, Hanby VI. Chow TT. HVAC system optimization for energy management by evolutionary programming, Energy and Buildings. 2006; 38:220-31. https://doi.org/10.1016/j.enbuild.2005.05.008.

8. Wang L, Gwilliam D. Discussion of Strategies for UK Zero Energy Design, Paper Presented at the 2nd PALENC Conference and 28th AIVC Conference on Building Low Energy Cooling and Advance Ventilation, Grete Island, Greece Technologies in the 21st century, Crete Island, Greece; 2007. p. 247.

9. Verbeek G, Hens H. life cycle optimization of extremely low energy dwelling, Journal of Building Physics. 2007; 31(2):143-77. https://doi.org/10.1177/1744259107079880.

10. Rijal HB, Tuohy P, Nicol F, Humphreys MA, Samuel A, Clarke J. Developing of adaptive window-opening algorithm to predict the thermal comfort. Energy use and overheating in building, Journal of Building Performance Simulation. 2008; 1(1):17-30. https://doi. org/10.1080/19401490701868448.

11. Trcka M, Hensen JLM. Wetter M. Co-simulation of innovation integrated HVAC system in building, Journal of Building Performance Simulation. 2009; 2(3):209-30. https://doi.org/10.1080/19401490903051959.

12. Urbikain MK, Sala JM. Analysis of different models to estimate energy savings related to windows in residential buildings, Energy and Buildings. 2009; 41:687-95. https:// doi.org/10.1016/j.enbuild.2009.01.007.

13. Zlatanovic I, Gligorevic K, Ivanovic S, Rundonja N. Energysaving estimation model for hypermarket HVAC system applications, Energy and Buildings. 2011; 43:3353-59. https://doi.org/10.1016/j.enbuild.2011.08.035.

14. Bomberg $M$, Thorsell $T$. Integrated Methodology for evaluation of energy performance of the building enclosures- Part1: Test program development, Journal of Building Physics. 2008; 32(1):33-48. https://doi. org/10.1177/1744259108093316.

15. Thorsell $T$, Bomberg M. Integrated methodology for evaluation of energy performance of the building enclosures: Part 3- uncertainty in thermal measurements, Journal of Building Physics. 2011; 35(1):83-96. https://doi. org/10.1177/1744259111404381.

16. Yu S, Bomberg M, Zhang X. Integrated methodology for evaluation of energy performance of the building enclosures: 
Part 4- material characterization for input to hydrothermal models, Journal of Building Physics. 2011; 35(3):194-212. https://doi.org/10.1177/1744259111420071.

17. Mora R, Bitsuamlak G, Horvat M. Integrated life-cycle design of building enclosures, Building and Environment. 2012; 46:1469-79. https://doi.org/10.1016/j.buildenv.2011.01.018.

18. Kaynakli O. A study on residential heating energy requirement and optimum insulation thickness, Renewable Energy. 2008; 33:1164-72. https://doi.org/10.1016/j. renene.2007.07.001.

19. Al-Sanea SA, Zedan MF Improving thermal performance of building walls by optimizing insulation layer distribution and thickness for same thermal mass, Applied Energy. 2011; 88:3113-24. https://doi.org/10.1016/j.apenergy.2011.02.036.

20. Serghides KD, Georgakis CG. The building envelop of Mediterranean houses: Optimization of mass and insulation, Journal of Building Physics. 2012; 36(1):83-98. https://doi.org/10.1177/1744259112448369.

21. Attia S, Hamdy M, O’Brien W, Calucc S. Assessing gaps and need for integrating building performance optimization tools in net zero energy building design, Energy and Buildings. 2014; 60:110-24. https://doi.org/10.1016/j. enbuild.2013.01.016.

22. Attia S, Herde AD, Gratia E, Hensen .M. Achieving informed decision-making for net zero energy buildings design using building performance simulation tools, Building Simulation. 2013; 6:3-21. https://doi.org/10.1007/ s12273-013-0105-z.

23. Heibati SM, Atabi F. Integrated dynamic modelling for energy optimization in the building: part 1: The development of the model, Journal of Building Physics. 2013; 37(1):28-54. https://doi.org/10.1177/1744259113475543.

24. Heibati SM, Atabi F. Integrated dynamic modelling for energy optimization in the building: Part 2: An application of the model to analysis of XYZ building, Journal of Building Physics. 2013; 37(2):153-69. https://doi. org/10.1177/1744259112474873.

25. Berggren B, Widen J, Karlsson B, Wall M. Evaluation and Optimization of a Swedish Net ZEB- using Load Matching and Gird Interaction Indicators. Paper presented at the 1st Building Simulation and Optimization Conference; 2012.

26. Salom J, Marszal AJ, Candanedo J, Lindberg K.B. Analysis of load match and grid interaction indicator in net energy building with simulated and monitored data, Applied Energy. 2014; 136:119-31. https://doi.org/10.1016/j.apenergy.2014.09.018.

27. Salom J, Widen J, Candanedo J, Lindberg KB. Analysis of grid interaction indicators in net zero-energy building with sub-hourly collected data, Advance in Building Energy
Research. 2015; 9(1):1-18. https://doi.org/10.1080/175125 49.2014.941006.

28. Mohamed A. Fulfillment of Net-Zero Energy Building (NZEB) with four metrics in a single family house with different heating alternative, Applied Energy. 2014; 114:385-99. https://doi.org/10.1016/j.apenergy.2013.09.065.

29. Gallo A, Molina BT, Prodanovic M, Aguilar JG. Analysis of net Zero- Energy Building in Spain. Integration of PV, solar domestic hot water and air- conditioning system, Energy Proccedia. 2014; 48:828-36. https://doi.org/10.1016/j.egypro.2014.02.096.

30. Mohamed A, Cao S, Hansan A, Siren K Selection of microcogeneration for net zero energy buildings (NZEB) using weighted energy matching index, Energy Buildings. 2014; 80:490-503. https://doi.org/10.1016/j.enbuild.2014.05.055.

31. Kusiak A, Li M, Tang F. Modeling and optimization of HVAC energy consumption, Applied Energy. 2010; 87:3092-102. https://doi.org/10.1016/j.apenergy.2010.04.008.

32. Kusiak A, Xu G. modeling and optimization of HVAC system using a dynamic neural network, Energy. 2012; 42:241-50. https://doi.org/10.1016/j.energy.2012.03.063.

33. Kusiak A, He XIaofei, Zhang Z. Performance optimization of HVAC systems with computational intelligence algorithms, Energy and Buildings. 2014; 81:371-80. https://doi. org/10.1016/j.enbuild.2014.06.021.

34. Kusiak A, Xu G, Zhang Z. Minimization of energy consumption in HVAC systems with data-driven models and interior-point method, Energy Conversion and Management. 2014; 85:146-53. https://doi.org/10.1016/j. enconman.2014.05.053.

35. Afram A, Janabi-Sharifi A. Review of modelling method for HVAC system, Applied Thermal Engineering. 2014; 67:507-19. https://doi.org/10.1016/j.applthermaleng.2014.03.055.

36. Afram A, Janabi-Sharifi A. Gray-box modeling and validation of residential HVAC system for control system design, Applied Energy. 2015; 137:134-50. https://doi. org/10.1016/j.apenergy.2014.10.026.

37. Lu Y, Wang S, Zhao Y, Yan C. Renewable energy system optimization of low/zero energy buildings using singleobjective and multi- objective optimization method, Energy and Buildings. 2015; 89:61-75. https://doi.org/10.1016/j. enbuild.2014.12.032.

38. Holman JP. Heat Transfer. Tenth Edition McGraw Hill; 2010.

39. American society of Heating Refrigeration Air-conditioning Engineering (USA) ASHRAE Handbook-HVAC Applications (2). Date accessed: 2010. https://www.ashrae. org/technical-resources/ashrae-handbook/table-of-contents-2015-ashrae-handbook-hvac-applications.

40. American society of plumbing engineers (USA) ASPE Plumbing Engineering Design Handbook (2). Date accessed: 2010. http://aspe.org. 
41. Matuska T. A simple Trombe wall: Comparison of different glazing's. In: Proceeding of the 3rd International Solar Energy Society Eurosun. Copenhagen; 2000.

42. Clean energy decision support (Canada). Ground -source heat pump project analysis, Retsereen engineering and cases textbook: Minister of natural recourses Canada. Date accessed: 2011. www.retscreen.net/ang/textbook_gshp. html.

43. Hottel HC, Whillier W. Evaluation of flat plate solar collector performance. Paper presented at Transaction Conference Use of Solar Energy Thermal Processes. Tuscon AZ; 1955. 169(1). 